\title{
Non-covalent dimerisation of a bicyclic aromatic oligomer via loop-loop interlocking in the solid state
}

\author{
Howard M. Colquhoun, ${ }^{* a}$ Fabio Arico ${ }^{a}$ and David J. Williams*b \\ a Department of Chemistry, University of Reading, Whiteknights, Reading, UK RG6 6 AD. \\ E-mail: h.m.colquhoun@rdg.ac.uk; Fax: (+)44 118931 6196; Tel: (+)44 1189316196 \\ ${ }^{b}$ Department of Chemistry, Imperial College, South Kensington, London, UK SW7 2 AY. \\ E-mail: djw@ic.ac.uk; Fax: (+)44 207594 5835; Tel: (+)44 2075945780
}

Received (in London, UK) 14th August 2002, Accepted 1st October 2002

First published as an Advance Article on the web 18th October 2002

\begin{abstract}
A macrobicyclic ether-ketone oligomer containing twenty aromatic rings has been isolated from the products of nucleophilic condensation between 4,4'-(9-fluorenylidene)diphenol and 1,3,5tris(4'-fluorobenzoyl)benzene. Reduction of all six carbonyl groups to methylene units yields a derivative which exhibits non-covalent dimerisation in the crystalline state via shape-complementary interlocking of fluorenylidene-containing "loop" regions.
\end{abstract}

At the quaternary level of molecular structure, proteins and polypeptides frequently associate into dimers or higher-level assemblies via non-covalent binding between externally accessible "loop" regions of the interacting chains. ${ }^{1}$ Examples of this are found in the enzyme HIV 1 protease, which comprises two nearly-identical polypeptide chains, ${ }^{2}$ and in the antibiotic vancomycin, where the tricyclic glycopeptide dimerises by quadruple hydrogen-bond formation between identical regions of two molecules. ${ }^{3}$ In synthetic oligomer systems, Cram and co-workers have reported non-covalent homo-dimerisation of polycyclic "velcrands", both in solution and in the crystalline state, driven by a combination of shape-complementary van der Waals interactions and solvophobic effects. ${ }^{4}$ Macrocyclic phenylene-ethynylene oligomers have also been shown to aggregate into rather less well-defined assemblies via $\pi-\pi$ stacking interactions, ${ }^{5}$ and in the present communication we describe a striking example of shape-complementary, noncovalent dimerisation in a new and fully-defined, macropolycyclic aromatic oligomer system.

It has recently been reported that nucleophilic aromatic polyetherification reactions which would normally lead to highly cross linked network-polymer structures can also, if carried out under pseudo-high dilution conditions, afford previously unknown types of macrobicyclic and macropolycyclic cage-molecules. ${ }^{6}$ Here we describe the cyclo-condensation of 1,3,5-tris(4-fluorobenzoyl)benzene with 4,4'-(9-fluorenylidene)diphenol (Scheme 1) and the isolation, from a complex mixture of products, of the cage-type compound 1 in $c a$. 3\% yield. Both spectroscopic $\left({ }^{1} \mathrm{H}\right.$ and ${ }^{13} \mathrm{C}$ NMR, IR and MS) and elemental analyses are fully consistent with the proposed structure, as is the extraordinarily high melting point of $\mathbf{1}$ which, at $528^{\circ} \mathrm{C}$ (determined by DSC), is indicative of an extremely rigid molecular structure.

Single crystals of 1 suitable for X-ray analysis proved elusive and so, in an attempt to obtain a more tractable derivative, the carbonyl groups were reduced with triethylsilane and trifluoroacetic acid to give the methylene bridged cage-compound $\mathbf{2}$ in $70 \%$ isolated yield. Crystals of this compound grown from dichloromethane/acetonitrile - though displaying an unusual

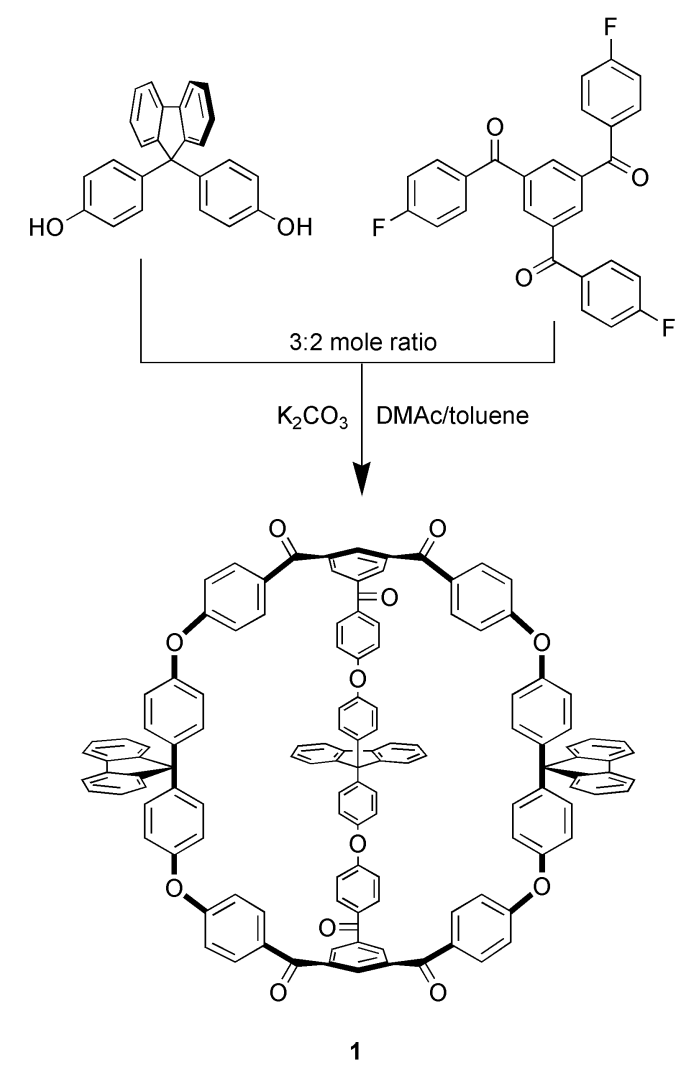

Scheme 1 Synthesis of oligomer 1 by nucleophilic cyclo-condensation under pseudo-high dilution conditions.

tubular habit-were of much better quality than those of $\mathbf{1}$, and ultimately enabled the X-ray structure of $\mathbf{2}$ to be determined. As shown in Fig. 1, the molecule adopts a conformation in which two arms of the cage lie in very close proximity to one another, with the third arm forming a rather open and accessible "loop" having a substantial free pathway. The most remarkable feature of the structure however is that molecules of $\mathbf{2}$ form mutually-interpenetrating, non-covalent dimers, in which the two components are related by a crystallographic inversion centre (Fig. 2). The fluorenylidene residue of each "loop-region" passes completely through the corresponding loop of a second, symmetry-related molecule, so that the two molecules become deeply interlocked. The shape of the fluorenylidene residue is evidently complementary to that of loop region in which it is embedded, and inspection of intermolecular contacts reveals that the dimer is in fact stabilised 


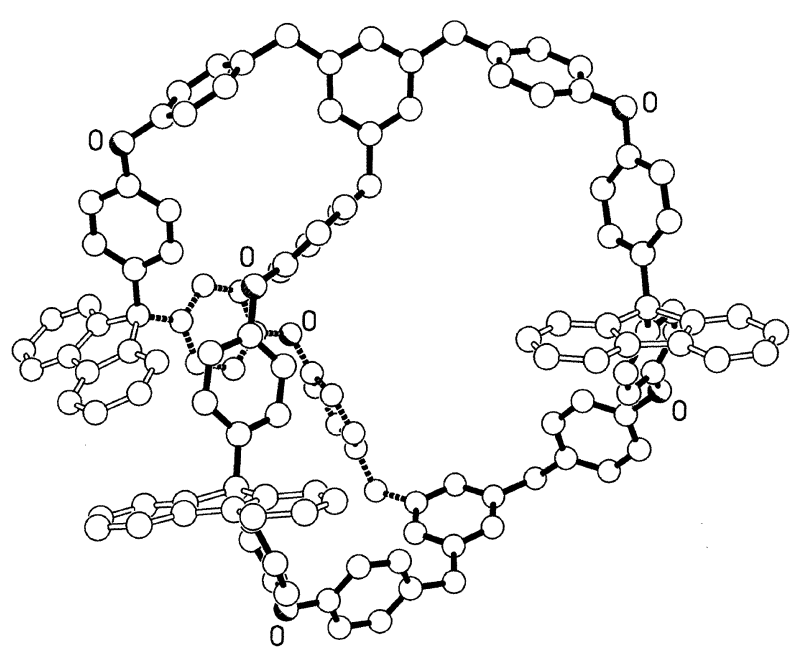

Fig. 1 X-Ray structure of one molecule of the reduced macrobicycle 2 (hydrogen atoms are omitted for clarity).

by the cumulative effects of six $\mathrm{C}-\mathrm{H} \cdots \pi$ interactions, with $\mathrm{H} \cdots \pi_{\text {centroid }}$ distances in the range 2.70 to $3.01 \AA$. Despite the largely aromatic nature of compound 2 , there is no evidence for $\pi-\pi$ stacking interactions between the associating molecules. It is also significant that, even though the hexafluoroisopropylidene analogue of $\mathbf{2}$ adopts a rather similar overall molecular conformation, ${ }^{6}$ no interlocking is observed in this case, perhaps because of the absence of shape-complementarity with the loop region which here is provided by the fluorenylidene residue.

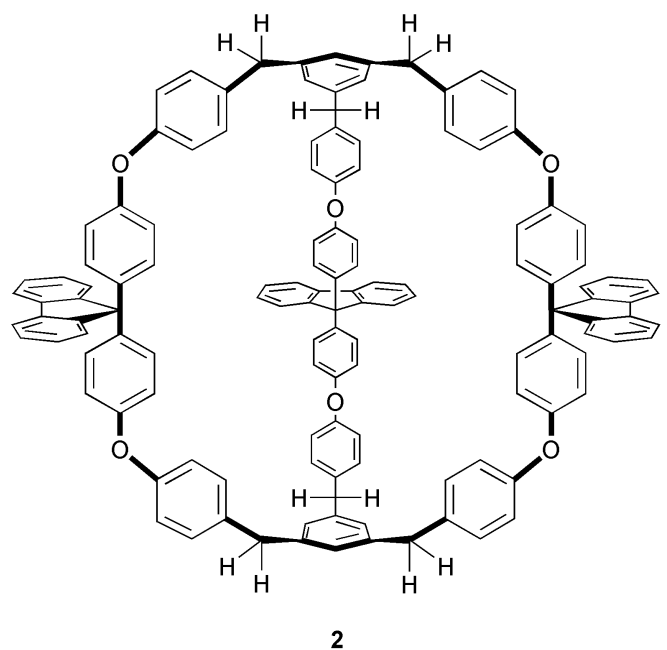

The present structure represents a particularly dramatic case of molecular interpenetration leading to non-covalent dimerisation, but it is possible that this type of behaviour will not prove uncommon for large and relatively rigid macrocyclic systems. The loops and cavities of such molecules cannot be filled by conformational collapse (as occurs in more flexible macrocyclic systems such as the crown ethers ${ }^{7}$ and macrocyclic alkanes $^{8}$ ) so that, where a degree of shape-complementarity exists, mutual interpenetration and non-covalent dimerisation will be favoured. A monocyclic aromatic ether-sulfone containing 12 aromatic rings has for example also been shown to form dimers in the solid state, each comprising a closelyinterpenetrating pair of molecules which are themselves folded approximately into the shape of a tennis-ball seam. ${ }^{9}$

Although evidence for shape-complementary macrocyclic dimerisation of the type reported here, and in ref. 9, is currently limited to the solid state, the reduction of non-polar surface area achieved by dimerisation suggests that solvophobic effects in polar solvents should also favour solvent-dependent

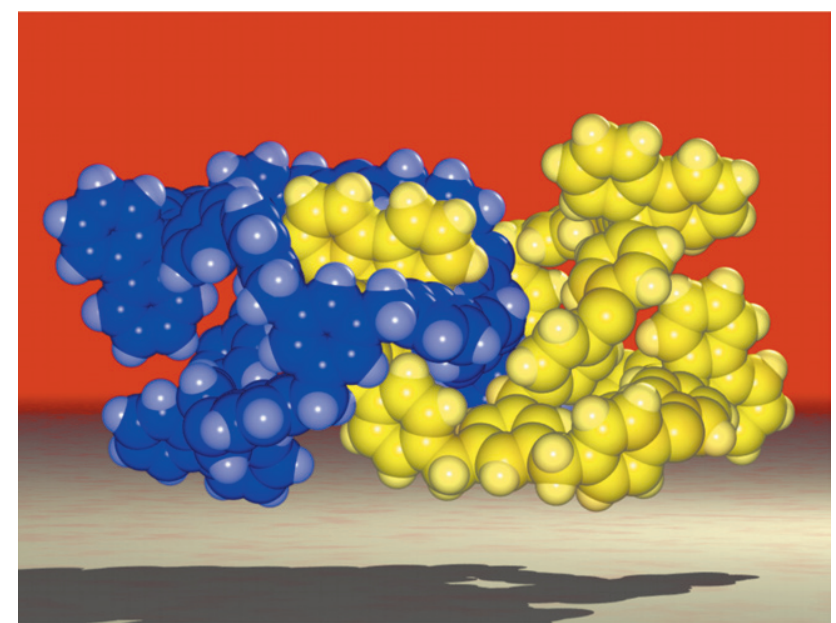

Fig. 2 Space-filling representation of the non-covalent dimer of $\mathbf{1}$ formed by double-interlocking of loops and fluorenylidene residues in the crystalline state. (The second interlocking region, involving a "yellow" loop and a "blue" fluorenylidene unit, is not visible in this view.) The overall dimensions of the dimer are ca. $32 \times 20 \times 17 \AA$

dimerisation in solution. ${ }^{4 c}$ This possibility is now under investigation.

\section{Experimental}

\section{Synthesis of 1}

A solution of 1,3,5-tris(4-fluorobenzoyl)benzene (2.10 g, 4.72 $\mathrm{mmol}$ ) and 4,4'-(9-fluorenylidene)diphenol (2.48 g, $7.10 \mathrm{mmol})$ in dimethylacetamide (DMAc, $120 \mathrm{~mL}$ ) was added over $30 \mathrm{~h}$ using a syringe pump to a refluxing suspension of anhydrous potassium carbonate $(2.56 \mathrm{~g}, 18.52 \mathrm{mmol})$ in a mixture of DMAc $(200 \mathrm{~mL})$ and toluene $(100 \mathrm{~mL})$ under nitrogen. The mixture was refluxed for a further $4 \mathrm{~h}$ and then filtered while hot to remove insoluble salts. Deionised water $(800 \mathrm{~mL})$ containing $\mathrm{HCl}(1 \mathrm{~mL})$ was added slowly to the solution, giving a yellow solid, which was collected by filtration and dried under vacuum at $70^{\circ} \mathrm{C}$. Gradient elution chromatography with DCM/EtOAc $(99 / 1$ to $90 / 10 \mathrm{v} / \mathrm{v})$ on silica gel enabled isolation of the macrobicyclic ether-ketone $1(0.13 \mathrm{~g}, 3 \%$ yield $)$. Compound 1 showed a m.p. of $528^{\circ} \mathrm{C}$ by DSC, and in the mass spectrum (MALDI-TOF, $\mathrm{CF}_{3} \mathrm{CO}_{2} \mathrm{Na}$ cationising agent) gave a molecular ion at $1843.3[\mathrm{M}+\mathrm{Na}]^{+}$. Calc. for $\mathrm{C}_{129} \mathrm{H}_{78} \mathrm{O}_{12} \mathrm{Na}, 1843.0 .{ }^{1} \mathrm{H}$ NMR $\left(\mathrm{CDCl}_{3}, 250 \mathrm{MHz}\right) \delta$ (ppm): $6.87(\mathrm{~d}, J=8.7 \mathrm{~Hz}, 12 \mathrm{H}), 7.0(\mathrm{~d}, J=8.7 \mathrm{~Hz}, 12 \mathrm{H})$, $7.2(\mathrm{~d}, J=8.3 \mathrm{~Hz}, 12 \mathrm{H}), 7.2-7.4(\mathrm{~m}, 18 \mathrm{H}), 7.73(\mathrm{~d}, J=6.8$ $\mathrm{Hz}, 6 \mathrm{H}), 7.77(\mathrm{~d}, J=8.7 \mathrm{~Hz}, 12 \mathrm{H}), 8.26(\mathrm{~s}, 6 \mathrm{H}) .{ }^{13} \mathrm{C} \mathrm{NMR}$ $\left(\mathrm{CDCl}_{3}, 62.5 \mathrm{MHz}\right) \delta$ (ppm): 64.9 (aliphatic fluorenylidene carbon), 118.07, 119.9, 120.8, 126.4, 128.2, 128.32, 130.1, 131.5 (C ortho to carbonyl and meta to ether), 132.8 (C ipso to carbonyl and para to ether), 134.2, 138.7, 140.5, 142.6, $151.2, \quad 154.6,162.3,194.1$ (C carbonyl). IR (KBr) 1667 $(v \mathrm{C}=\mathrm{O}), 1592,1497,1243(v \mathrm{C}-\mathrm{O}) \mathrm{cm}^{-1}$. Anal. calc. for $\mathrm{C}_{129} \mathrm{H}_{78} \mathrm{O}_{12} \cdot 0.5 \mathrm{CH}_{2} \mathrm{Cl}_{2}$ : C, 83.52; $\mathrm{H}, 4.24$. Found: $\mathrm{C}, 83.79$; $\mathrm{H}, 4.24 \%$.

\section{Synthesis of 2}

A mixture of macrobicycle $1(0.060 \mathrm{~g}, 0.033 \mathrm{mmol})$, trifluoroacetic acid $(2.5 \mathrm{~mL})$ and dichloromethane $(0.7 \mathrm{~mL})$ was magnetically stirred under nitrogen for $30 \mathrm{~min}$, during which time the compound dissolved completely to give a light yellow solution. Triethylsilane $(383 \mu \mathrm{L}, 2.37 \mathrm{mmol})$ was added 
dropwise over $10 \mathrm{~min}$ and the mixture was stirred at $20^{\circ} \mathrm{C}$ for $48 \mathrm{~h}$. Methanol $(10 \mathrm{~mL})$ was then added to the solution and the precipitated white solid (2) was collected by filtration and dried under vacuum (70\% yield). The mass spectrum (MALDI-TOF) of 2 showed a molecular ion at 1759.8. [M+Na] $]^{+}$, Calc. For $\mathrm{C}_{129} \mathrm{H}_{90} \mathrm{O}_{6} \mathrm{Na}, 1759.1 .{ }^{1} \mathrm{H}$ NMR $\left(\mathrm{CDCl}_{3}, 250 \mathrm{MHz}\right) \delta$ (ppm): $3.9(\mathrm{~s}, 12 \mathrm{H}), 6.8(\mathrm{~d}, J=8.7 \mathrm{~Hz}, 12 \mathrm{H}), 6.85(\mathrm{~s}, 6 \mathrm{H})$ $6.92(\mathrm{~d}, J=8.7 \mathrm{~Hz}, 12 \mathrm{H}), 7.10(\mathrm{~d}, J=8.6 \mathrm{~Hz}, 12 \mathrm{H}), 7.15$ $(\mathrm{d}, J=8.9 \mathrm{~Hz}, 12 \mathrm{H}), 7.23-7.42(\mathrm{~m}, 18 \mathrm{H}), 7.8(\mathrm{~d}, J=7.3$ $\mathrm{Hz}, 6 \mathrm{H}) .{ }^{13} \mathrm{C} \mathrm{NMR}\left(\mathrm{CDCl}_{3}, 62.5 \mathrm{MHz}\right) \delta(\mathrm{ppm}): 41.4,64.7$, $118.2,119.84,120.6,126.4,127.7,127.9,128.2,129.7,130.5$, $136.5,140.4,140.7,141.8,151.7,155.4,156.9$. IR (KBr) $1599,1498,1238 \mathrm{~cm}^{-1}$. Anal. Calc. For $\mathrm{C}_{99} \mathrm{H}_{84} \mathrm{O}_{6} \cdot 0.5 \mathrm{CH}_{2-}$ $\mathrm{Cl}_{2}$ : C, 87.47; H, 5.12. Found: C, 87.62; H, 5.44\%. Single crystals of $\mathbf{2}$ were grown by slow evaporation of a solution in dichloromethane/acetonitrile.

\section{Crystal data for 2}

$\mathrm{C}_{129} \mathrm{H}_{90} \mathrm{O}_{6} \cdot 5 \mathrm{CH}_{3} \mathrm{CN} \cdot \mathrm{CH}_{2} \mathrm{Cl}_{2}, \quad M_{\mathrm{r}}=2026.21$, triclinic, $P \overline{1}$, $a=14.5841(12), \quad b=18.0586(12), \quad c=22.677(2) \AA, \quad \alpha=$ 69.951(6), $\beta=77.476(6), \gamma=89.341(7)^{\circ}, V=5464.1(7) \AA^{3}$, $T=203 \mathrm{~K}, Z=2, D_{\mathrm{c}}=1.232 \mathrm{~g} \mathrm{~cm}^{-3}, \mu\left(\mathrm{Cu}_{\mathrm{K} \alpha}\right)=1.018$ $\mathrm{mm}^{-1}, \quad F(000)=2128$. Independent measured reflections 151814. $R$ (int) $=0.0382 . \quad R_{1}=0.0557, \quad w R_{2}=0.1522$ for 11912 independent observed reflections $\left[2 \theta \leq 120^{\circ}, I>2 \sigma(I)\right]$. One of the solvating acetonitrile molecules and the dichloromethane were so disordered that their individual atomic positions were not resolvable. The number of solvent molecules and their contribution to the structure factors was estimated using the program PLATON/SQUEEZE. ${ }^{10}$
CCDC reference number 192519. See http://www.rsc.org/ suppdata/nj/b2/b208002h/ for crystallographic data in CIF or other electronic format.

\section{References}

1 Protein structure, ed. T. E. Creighton, IRL Press, Oxford, 1989.

2 A. Wlodawer, M. Miller, M. Jaskolski, B. K. Sathyanarayana, E. Baldwin, I. T. Weber, L. M. Selk, L. Clawson, J. Schneider and S. B. Kent, Science, 1989, 245, 616.

3 D. H. Williams and B. Bardsley, Angew. Chem., Int. Ed., 1999, 38, 172 .

4 (a) J. A. Bryant, C. B. Knobler and D. J. Cram, J. Am. Chem. Soc., 1990, 112, 1254; (b) J. A. Bryant, J. L. Ericson and D. J. Cram, J. Am. Chem. Soc., 1990, 112, 1255; (c) D. J. Cram, H. J. Choi, J. A. Bryant and C. B. Knobler, J. Am. Chem. Soc., 1992, 114, 7748 .

5 (a) J. S. Moore, Acc. Chem. Res., 1997, 30, 402; (b) A. S. Shetty, J. Zhang and J. S. Moore, J. Am. Chem. Soc., 1996, 118, 1019; (c) Y. Tobe, N. Utsumi, A. Nagano and K. Naemura, Angew. Chem., Int. Ed., 1998, 37, 1285; (d) Y. Tobe, N. Utsumi, K. Kawabata, A. Nagano, K. Adachi, M. Sonoda, K. Hirose and K. Naemura, J. Am. Chem. Soc., 2002, 124, 5350; (e) S. Höger, K. Bonrad, A. Mourran, U. Beginn and M. Möller, J. Am. Chem. Soc., 2001, 123, 5651; $(f)$ K. Nakamura, H. Okubo and M. Yamaguchi, Org. Lett., 2001, 3, 1097.

6 H. M. Colquhoun, F. Arico and D. J. Williams, Chem. Commun., 2001, 2574.

7 J. van Eerden, A. Roos, S. Harkema, P. D. J. Grootenhuis and D. N. Reinhoudt, Acta Crystallogr., Sect. C: Cryst. Struct. Commun., 1987, 43, 799.

8 T. Trzebiatowski, M. Dräger and G. R. Strobl, Makromol. Chem., 1982, 183, 731 .

9 I. Baxter, A. Ben-Haida, H. M. Colquhoun, P. Hodge, F. H. Kohnke and D. J. Williams, Chem. Commun., 1998, 2313.

10 P. van der Sluis and A. L. Spek, Acta Crystallogr., Sect. A. Fundam. Crystallogr., 1990, 46, 194. 